By EDWIN T. COMAN, JR.

\title{
Advancing the University Library Frontier
}

Edwin T. Coman, Jr., is librarian, Graduate School of Business Library, Stanford University, California.

$\mathrm{T}$ HE LIBRARIAN OWES a responsibility to the faculty, students, alumni, and to his library to make it a useful and strong institution through close cooperation with groups within and without the university and adequate publicity regarding library resources and activities. As a librarian dealing with graduates of a considerable number of universities and colleges, I am continually surprised at the inability of students to use the library effectively and their undeveloped appreciation of the cultural value of books.

While it is primarily the faculty's responsibility to develop reading interests in students, nevertheless, librarians should share this responsibility. Save in a few notable instances, we are failing miserably to develop permanent reading interests in students. Too often the attitude is that we have a fine collection of books, adequately housed and cataloged, and that it is the student's own responsibility to come and use it. The student of today is the alumnus of tomorrow and in these days of shrinking endowment income the library cannot have too many alumni friends. If a student in his undergraduate days learns to use the library and acquires a genuine interest in books, he is apt to become an outpost for the library.
Any program to link the student and the alumnus to the library should be carefully planned over a long period and should be coordinated with the teaching departments, the alumni organizations, and any special activities of the library. Too often a program is abandoned because of lack of general response and support, the inability to reach large numbers of students, and in some instances, perhaps, because the library staff does not want to be bothered with the extra work involved. Much of this discouragement can be avoided if a flexible plan is worked out with the realization that development will take place over a longer period. Judicious cooperation with the teaching departments and administration will also help to smooth the way. The librarian should be aware of the needs and interests of his faculty and in turn keep them informed as to additions to the library and of notable collections. Very often a member of the faculty, through his outside contacts, can be of great assistance in building up the library where it is weak. This interchange also brings a mutual understanding of the activities of both departments. When Prof. William Lyon Phelps paraded in cap and gown at the head of his class to deposit two first editions of Browning in the Yale University Library, the undergraduates were made very much aware of the treasures stored in that building. The active interest of the 
faculty also can be of the greatest assistance in focusing student interest in the library.

The library's relationships fall naturally into three parts-those with the faculty, the students, and the alumni. The obligations to the faculty and to the students should take first place and this includes teaching the student how to use the library effectively, making him appreciate its resources and possibilities as a direct help to him with the task at hand, and attempting to arouse his interest in the cultural value of books.

\section{Student Orientation}

The average library orientation course for freshmen is useless. The new student, suddenly placed in an unfamiliar environment, is so confused during his first few weeks that he is unable to assimilate most of the information put before him. If there must be a general orientation course it would be better to plan it for a period toward the middle of the first semester when the freshman has begun to know his way around. A much better way is to seek the cooperation of the instructors in various subject fields so that the library and the work in hand may be closely related in the mind of the student. The case method, whereby the student learns how to use the library while he is writing a report, will bring more appreciation of the library to him than a month of lectures. It also enables the librarian to appeal to the students through their specific interests. An added advantage is that the groups are smaller and the instruction can be on a more nearly individual basis. The plan of conducting classes in the library as worked out by B. Lamar Johnson at Stephens College seems an admirable one where facilities are available and the groups involved are not too large.

Further cooperation with other departments in the compilation of reading lists and assistance to students in the preparation of bibliographies, both as to form and content, widen the influence of the library. Several of the departments in the physical and natural sciences at Stanford University make a strong effort to acquaint their students with the reference tools and general works in their fields, thereby making the students much more effective in their use of the library.

\section{Stimulation of Cultural Reading}

A large proportion of the present generation of college students has a definite lack in its cultural background-there is little evidence of contact with books. This is understandable because of the absence of effective libraries in elementary and high schools, the absence of public libraries in many communities, the lack of books in homes, and the general trend toward commercialized entertainment. It is the duty of the library at least to expose the students to the enjoyment of books. A browsing room equipped with challenging reading matter, tastefully furnished with comfortable chairs and ashtrays, is good bait to interest students in recreational reading. Another way of enhancing the book interest is the small library in the living unit.

There is too much of a tendency to say to the student: "Here is a bookread it." If the student can be aroused to ask for books a long step has been taken to interest him in the library. The encouragement of the building up of a personal library on the part of the student is decidedly worth while and can be done through exhibits and the offering of prizes for the best student collections. The stu- 
dent book contests at Yale produced some astonishingly fine collections of first editions and fine bindings. The students who respond are well on the way to becoming book collectors and upon graduation should become key men in the library's alumni contact.

The library owes an obligation to the undergraduate and there is evidence that to date it has not discharged it very well. Furthermore, this obligation continues, in lesser degree, to the alumnus. It is much to the advantage of the library for the alumni and other individuals to develop an awareness of the library, its needs, and problems.

\section{Mix with Alumni Groups}

Librarians tend too much to talk and associate with each other. This is all very pleasant and stimulating but we need to get out of our libraries and tell our stories to new groups who little understand the functions of either the library or the librarian. A certain amount of judicious mixing with alumni groups and business men in Rotary, Kiwanis, or other gatherings provides an opportunity, particularly if the librarian can speak on his favorite topics, to promote interest in the library.

As a part of a plan to further the library no opportunity to inform the public of the library's activities should be neglected. In addition to speeches before alumni groups, the more articles in alumni and other publications the better. A well thought out campaign of feature articles of newsworthy value can do much in dispelling ignorance. In connection with these articles it is well to note the suggestion of Willis Kerr, librarian of Claremont Colleges Libraries, where he points out that it is wise to let people know how they can help the library.
It is a truism that people can be most easily approached through their own interests and enthusiasms. It is a pity that librarians do not more fully utilize these opportunities. The man who is interested in some field to the point where he is anxious to know more about it can be fairly easily induced to transfer this interest into building up the library in his field. Many business men can be enlisted to contribute funds or books or both to enable the library to have material dealing with his business or industry. Of course, if a man is a collector, it is a simple matter to gain his interest in library activities and he very often arouses an interest in others with his enthusiasm.

This brings us naturally to the Friends of the Library organizations. It seems to be generally agreed that such groups should be distinct from the library. If the librarian has been able to develop any bibliographic enthusiasms among the students, such individuals should become, on graduation, a nucleus around which to form Friends of the Library. The most important ingredient is to have a few enthusiastic individuals with sufficient background and bibliographical skill to intelligently direct the group. The success of their activities is attested by the substantial gifts in money, valuable books, and manuscripts which they have been able to direct to libraries. They form excellent outposts for the library and also bring to it the very best kind of publicity.

\section{Gifts and Endowments}

The library particularly lends itself to gifts both large and small. Even two or three dollars buys one book and when properly acknowledged and plated with a gift plate makes the donor feel that he has made a tangible contribution to the li- 
brary. Funds from two thousand dollars, set up as an endowment, the income to purchase books in a specific field, can be of great assistance-providing the field is so broadly indicated as to impose no undue restrictions on the use of the funds. Another phase of the endowment is to utilize it as a memorial to an alumnus. This can be done by setting aside a memorial bookshelf for the books purchased with these funds; or better, from a library point of view, plating the books with a memorial bookplate and shelving them in their proper place in the general book collection.

The problem of building up a sustained and tangible interest in the library is not an easy one to solve. However, it is susceptible to solution if the librarian utilizes the same ingenuity as in the administration of his library, the selection of books, or the planning of a new building. The librarian must come out from behind the stacks and bring the library to the public, just as the manufacturer introduces a new product to the market. The campaign should be well integrated and tested over a sufficient length of time so that the unsuccessful features may be discarded and effort be concentrated on those that work. Many of the suggestions outlined in this paper have been tried in the Graduate School of Business Library and have been sufficiently successful to justify further activities and expansion along these lines. 